\title{
INVESTIGATION OF THE EFFECTS OF RETRO MUSIC ON CREATING A CONSUMER BRAND PERCEPTION WITH NEUROMARKETING TECHNIQUE
}

\author{
DOI: 10.17261/Pressacademia.2021.1437 \\ PAP- V.13-2021(26)-p.107-108
}

Tugce Ezgi Soyaltin ${ }^{1}$, Ceyda Aysuna Turkyilmaz ${ }^{2}$

${ }^{1}$ Istanbul Kultur University, Faculty of Economics and Administrative Sciences, Istanbul, Turkey. tesoyaltin@gmail.com, ORCID: 0000-0001-6564-0701

${ }^{2}$ Marmara University, Faculty of Business Administration, Istanbul, Turkey.

caysuna@marmara.edu.tr, ORCID: 0000-0002-9015-4980

To cite this document

Soyaltin, T.E., Aysuna Turkyilmaz, C. (2021). Investigation of the effects of retro music on creating a consumer brand perception with neuromarketing technique. PressAcademia Procedia (PAP), V.13, 107-108.

Permanent link to this document: http://doi.org/10.17261/Pressacademia.2021.1437

Copyright: Published by PressAcademia and limited licensed re-use rights only.

\begin{abstract}
Purpose- The aim of this study is to measure the responses of consumers to retro music by using neuromarketing methods and tools, and to try to understand their subconscious thoughts by revealing what changes these music caused consumers' brand perceptions.

Methodology- In line with the purpose of the research, one of the quantitative research methods is questionnaire technique, and one of the neuromarketing methods and techniques is the FNIRS Analysis Method (Neurometric Measurement) and GSR Analysis Method (Biometric Measurement), will be used. The study is designed to consist of two stages. In the first phase of the study, the survey will be applied to 300 people in order to create brand dimensions. Brand dimensions will be extracted from the obtained survey data. In the second phase of the study, it is planned to conduct an FNIRS and GSR Analysis experimental study with at least 30 volunteer participants. Participants will be made to watch a brand's commercial version without retro music and commercial versions with retro music, respectively. Before starting the study, the participants will be asked to declare their voluntary participation in this study by filling out the "Volunteer Participation Declaration Form" and "Research Declaration Form", which includes personal information and includes open-ended questions.

Findings- In the application part of our study, whether there is a positive effect of retro music on consumers' brand perceptions, neuroscientific differences between consumers' reactions to brands with and without retro music, and neuroscientific differences between the reactions consumers give when they hear retro music and other music, Whether retro music creates an emotional bond between consumers and brands will be try to be obtained through analysis.

Conclusion- As a result of the measurements made, the effects of retro music on the brand perception of consumers will be analyzed as a result of examining the electrical voltages resulting from the participants' brain waves and will be interpreted in the light of the data obtained. It is to be able to provide useful information to academia and the business world thanks to the data obtained and to contribute to the creation of the infrastructure that will enable these two worlds to act together interactively. In addition, it is to contribute to the establishment of special laboratories specific to the field by encouraging the increase of such experimental studies.
\end{abstract}

Keywords: Neuromarketing, music-brain relationship, retro music, brand perception, FNIRS \& GSR analysis methods JEL Codes: D11, D87, M31

\section{RETRO MÜZIĞiN TÜKETicileR ÜZERINDE MARKA ALGISI YARATMADAKi ETKILERININ NÖROPAZARLAMA ÇERÇEVESINDE INCELENMESi}

\section{ÖZET}

Amaç- Bu çalışmanın amacı, nöro pazarlama yöntem ve araçları kullanılarak tüketicilerin retro müziklere olan tepkilerini ölçmek ve bu müziklerin tüketicilerin marka algılamalarında ne gibi değişikliklere sebep olduğunu ortaya çıkararak bilinçaltındaki düşüncelerini anlamaya çalışmaktır.

Yöntem- Araştırmanın amacı doğrultusunda nicel araştırma yöntemlerinden anket tekniği ile nöropazarlama yöntem ve tekniklerinden FNIRS Analiz Yöntemi (Nörometrik Ölçüm) ile GSR Analiz Yöntemi (Biometrik Ölçüm) kullanılacaktır. Çalışma, iki aşamadan oluşacak şekilde tasarlanmıştır. Çalışmanın 1. aşamasında, marka boyutlarının oluşturulabilmesi için hazırlanan anket çalışması 300 kişiye uygulanacaktır. Elde edilen anket verilerinden marka boyutları çıkarılacaktır. Çalışmanın 2. aşamasında ise en az 30 gönüllü katılımcıyla birlikte FNIRS ve GSR Analiz 
deneysel çalışmasının gerçekleştirilmesi planlanmaktadır. Katılımcılara, sırasıyla bir markanın retro müzik kullanılmamış reklam versiyonu ile retro müzik kullanılmış reklam versiyonları izlettirilecektir. Çalışmaya başlamadan önce, katılımcılara kişisel bilgilerini içeren ve açık uçlu soruları kapsayan "Gönüllü Katılım Beyan Formu” ile "Araştırma Beyan Formu” doldurtularak yapılan bu araştırmaya gönüllü olarak katıldıklarını beyan etmeleri istenecektir.

Bulgular- Araştırmamızın uygulama kısmında, tüketicilerin marka algılamaları üzerinde retro müziğin pozitif yönde bir etkisinin, tüketicilerin retro müziğe sahip olan ve olmayan markalara verdikleri tepkiler arasında nöro bilimsel olarak anlamlı farklılıkların, tüketicilerin retro müzik ile diğer müzikleri duyduklarında verdikleri tepkiler arasında nöro bilimsel olarak anlamlı farklılıkların olup olmadığı, retro müziğin tüketiciler ile markalar arasında duygusal bir bağa yol açıp açmadığı yapılacak analizlerle elde edilmeye çalışılacaktır.

Sonuç- Yapılan ölçümler sonucu katılımcıların beyin dalgaları sonucu oluşan elektrik voltajları incelenerek retro müziğin tüketicilerin marka algısı üzerindeki etkileri analiz edilecek ve elde edilen veriler ışığında yorumlanacaktır. Elde edilen veriler sayesinde akademi ve iş dünyasına yararlı bilgiler sağlayabilmek ve bu iki dünyanın birlikte etkileşimli bir şekilde hareket etmesini sağlayacak alt yapının oluşturulmasına katkıda bulunabilmektir. Ayrıca bu tip deneysel çalışmaların arttırılmasının teşvik edilmesiyle birlikte alana özgü özel laboratuarların kurulmasına katkı sağlamaktır.

Anahtar Kelimeler: Nöropazarlama, müzik-beyin ilişkisi, retro müzik, marka algıSı, FNIRS ve GSR analiz yöntemi JEL Kodları: D11, D87, M31.

\section{REFERENCES}

Ait Hammou, K., Galib, M.H., \& Melloul, J. (2013), The Contribution of Neuromarketing in Marketing Research, Journal of Management Research, Vol.5, No.4, p.20-33.

Alyar, P., Pirtini, S. ve Yücel, N. (2021), Pazarlamada Yeni Eğilimler Açısından Nöropazarlama ve Algı Yönetimi Üzerine Bir Araştırma, Marmara Üniversitesi Öneri Dergisi, Cilt:16, Sayı:55, s.311-341.

Ayata, E. ve Aşkın, C. (2008), Müziğin Beynin Bilişsel Fonksiyonlarına Olan Etkisi, iтü Sosyal Bilimler Dergisi, Cilt:5, Sayı:2, s.13-22.

Cartwright, P.A., Besson, E. \& Maubisson, L. (2013), Nostalgia And Technology İnnovation Driving Retro Music Consumption, European Journal of Innovation Management, Vol. 16, Iss. 4, p.459- 494.

Cuesta, U., Martinez-Martinez, L. \& Nino, J.I. (2018), A Case Study in Neuromarketing: Analysis of the Influence of Music on Advertising Effectivenes through Eye-Tracking, Facial Emotion and GSR, European Journal of Social Science Education and Research, Vol.5, No.2, p. 7382.

Çakır, M.P., Çakar, T. ve Girişken, Y. (2018), An Investigation of The Neural Correlates of Purchase Behavior Through fNIRS, European Journal of Marketing, Vol.52, No.1/2, p.224-243.

Çuhadar, C.H. (2008), Müzik ve Beyin, Çukurova Üniversitesi Sosyal Bilimler Enstitüsü Dergisi, Cilt 17, Sayı 2, s.67-76.

Krampe, C., Gier, N.R. \& Kenning, P. (2018), The Application of Mobile fNIRS in Marketing Research-Detecting The "First-Choice-Brand" Effect, Frontiers in Human Neuroscience, 12:433.

Kindermann, H. \& Schreiner, M. (2017), IAT Measurement Method to Evaluate Emotional Aspects of Brand Perception-A Pilot Study, Information Systems and Neuroscience, Vol.25, p.167-173.

Küçün, N.T., Duman Alptekin, H. \& Çetin, C. (2020), Nöropazarlama Kapsamında Entegre Ölçüm Süreçlerinin Uygulanmasına Yönelik Bir Alan Yazın Taraması, Pazarlama Teorisi ve Uygulamaları Dergisi, Vol.6, No.2, p. 137-168.

Müllensiefen, D., Davies, C., Dossman, L., Hansen, J.L. \& Pickering, A. (2013), Implicit and Explicit Effects of Music on Brand Perception in TV Ads, Audio Branding Academy Yearbook, p.139-155.

YazıcI, D. (2017), Müziğin İnsan beyni Üzerindeki Etkisi, International Journal of Cultural and Social Studies, 3(1), 88-103.

Zimny, G.H. \& Weidenfeller, E.W. (1963), Effects of Music Upon GSR and Heart-Rate, The American Journaş of Psychology, Vol.76, No.2, p.311-314. 